\title{
The Caring Organization: Singularity, Incompleteness and Responsibility or why $5+1$ is not always 6
}

\author{
Ignaas Devisch ${ }^{*}$
}

\author{
Ghent University, De Pintelaan 185-6K3, 9000 Ghent, Belgium
}

\begin{abstract}
This article examines what is called the 'caring organization' out of the work of French philosopher Jean-Luc Nancy. Starting from two tales from Kafka and Borges, it analyzes Nancy's concept of community and singularity and their potential relevance for the area of social sciences. Thinking an organization from the perspective of singularity means that we no longer think in terms of an unchangeable essence. Nancy's notion of the singular goes the other way round: organizations are able to function because they differ from themselves and change all the time. An organization is but its components with their singular traits at every moment and these traits produce a singularized and thus necessarily temporary collective. As long as we start from identity as a substantial given, an unfruitful opposition is at work: the collective, the organization, is seen as the enemy of the subject and vice versa. Nancy's notion of singularity on the contrary, does not start from an opposition of two identities but from identities differing from themselves because they are understood as singular, changing entities; their singular characteristics potentially modify the whole as such.
\end{abstract}

Keywords: Jean-Luc Nancy, organization, identity, singularity.

\section{TWO SHORT STORIES}

This article obtains a discussion on the aspects of singularity and responsibility in what is called the 'caring organization' (N. Anderson \& Hughes Karen, 2010; Campbell, 2011; Forte, 2004; French \& Weis, 2000). A caring organization is what the word says it is: an organization that takes care for its employees. Though embedded in the literature on caring organizations, I will analyze this subject out of the work of French philosopher Jean-Luc Nancy.

To introduce what is at stake in Nancy's work and how it can be relevant to the area of business ethics, we will start with two short stories from two great and well known novelists, namely Franz Kafka on the one hand and Jorge Luis Borges on the other hand. We will use their stories as metaphors to introduce the topics we want to discuss.

First of all, a story from Borges. In The Analytical Language of John Wilkins (El idioma analítico de John Wilkins), Borges describes "a certain Chinese encyclopedia," the so called Celestial Emporium of Benevolent Knowledge, in which a classification of animals is given (Borges, 1984). The animals are divided into:

1. those that belong to the Emperor,

2. embalmed ones,

3. those that are trained,

*Address correspondence to this author at the Ghent University, De Pintelaan 185-6K3, 9000 Ghent, Belgium; Tel: 00-32-498574801;

E-mail: Ignaas.Devisch@UGent.be
4. suckling pigs,

5. mermaids,

6. fabulous ones,

7. stray dogs,

8. those included in the present classification,

9. those that tremble as if they were mad,

10. innumerable ones,

11. those drawn with a very fine camelhair brush,

12. others,

13. those that have just broken a flower vase,

14. those that from a long way off look like flies.

Obviously, in his text Borges laughs at scientific classification systems or taxonomies: every classification seems to include its own failure, Borges suggests, as animals can always be divided in all sorts of classes. Since the division of animals Borges writes about can only be called ridiculous, it is a metaphor to mock with the idea of the possibility to classify as such. We won't discuss this right now but will come back to this and apply it to the topic of the caring organization.

Secondly, we would like to discuss a short story from Franz Kafka. A very short story it is, and Max Brod, who edited Kafka's work, entitled it posthumously as 'Gemeinschaft' - the English translation is entitled with 'Fellowship', a very questionable translation (Kafka, 1983). It is a story of no more than fifteen lines about five people living together in a house. They were five friends we are told, everything was fine, but then a sixth wanted to join in and he refused to budge. The 
sixth came to disturb the party and throw the mathematics overboard. Although the friends wanted to include the sixth if the $5+1$ would have become 5 again, which means they would still be one community, a whole or a totality. Before the sixth arrived, the five were one, not because they really enjoyed each other but they were one because they lived together and therefore they are a community; the intruder came to turn this order upside down because the $5+1$ isn't actually 5 but 6 or even more than that.

To summarize the story: we were with five friends, we once came out of a house and people said, look, these five came out of this house. Since then, we live together and all went well until a sixth arrived. As such, we don't mind the sixth but the five of us are fine as it is; we don't know him and we don't want him. Although we don't know each other as well, we are used to each other now and we don't want to be six. Being with six doesn't make sense but being with five neither, but yet, we are used to it and we don't want a new community. We could make strong statements or detailed declarations but we won't do that. We don't declare anything. The sixth keeps on coming and although we push him away, he always returns. End of the story.

As is the case with Borges' celestial emporium, also Kafka's short story obviously discusses the matter of belonging to, of being part of a group or a kind, of being included or excluded. While Borges explicitly mocks about the attempt to classify living beings of all kinds, Kafka discusses the mathematical order we are familiar with. Apparently, when it comes down to being together, mathematics comes in trouble. Many social scientists, sociologists or philosophers have claimed this in the past: people living together in a community generate a reality of which a total sum is always more than the parts of it (Lopez, 2003). Consequently, the question of living together is not a problem where 1 and 1 is always 2. Kafka's short story poses this problem in the starkest terms: $5+1$ isn't five and therefore, the sixth, the intruder by coincidence, is not allowed to enter the house, not because the five hate him but simply they are five and belong together and he's not one of them. If $5+1$ would have been 5 , then it would have worked, but apparently $5+1$ will even be more than 6 .

\section{SINGULARITY}

Kafka's and Borges' tales expose a metaphysical problem we want to reveal throughout this article: the contingency of communities. The way five friends leave the house is quite everyday scenery. It could have been workers leaving their company by the end of the day. People come together, fall apart, make agreements, cross each other in the street, curse one another in traffic, etc. Of course, one shares more with certain others, and has more intense contact with this rather than that other; some might be completely alien to you while you cannot get enough of others. Not all experiences are equal, or even important, but all fall within the frame of what we could describe as everyday encounters.

Kafka's story is intriguing because the five also operate in this everyday mode, but nevertheless privilege one meeting so as to surmount the everydayness and attain an authentic existence. They exploit a banal meeting in order to set up a community to which only they belong, excluding everyone else. Despite their vague awareness that their community is nothing more than a banal meeting, they institute a communality where the shared experience of their contingent meeting undergoes a sort of process of concretization and seems to harden into an essence, a first cause or principle so as to overcome the order of contingency. They take this proclaimed essence so as to erect a barrier between themselves and others.

What Kafka's and Borges' stories indicate so beautifully here is that this barrier is itself of the order of the contingent, so that the whole operation of marking out the community is supported a priori by a failure. Every community is also a contingent community but most often forgets this contingency in order to put up a barrier between the inside and the outside, between the members of the community and the intruders. Then community becomes an imaginary whole (B. Anderson, 1999), an organic entity which seems to be natural in the way its barriers are installed.

When thinking about an organization, this is an important topic. Although its etymology refers to 'organ' or 'organic' and therefore includes the suggestion of a 'natural belonging together', most often an organization is a very contingent entity: people come and go, their origin and background is very diverse, as are their ethical values or cultural priorities; and most important, their belonging to the organization is only a part of their human being. Who they actually are, is quite a mystery since they are only partaking the organization because they want to or have to do their job.

Maybe more than we could have imagined when we read the story, an organization has all characteristics of 
Kafka's five friends leaving their house: they are one but their being-one is highly contingent. More emphatically, only because others have said that these five came out of a house together they belong together as this five. Through this everyday meeting, they have been bound to one another although the meaning of it escapes them. Their togetherness thus rests on chance. They share experiences but apparently have nothing in common, no essence that binds or drives them together. Why this is, we do not know - how would it be any other way in Kafka- but the fact that they are together is something they certainly know well and it is precisely because they are together that they stay together.

In Kafka's tale the connection between the five people who left the house is profoundly contingent. It could just as easily have been a coming together of four people sitting in a waiting room, waiting for the doctor together. Nevertheless, the five subsequently forget this contingency and interpret their shared experience as a first cause. The contingent fact that they came out of a house together as five people becomes a necessity: they cannot be otherwise than five, they are these five and not six. Their shared experience is the basis for their continuing on like this. Without a clear 'why' at the foundation of their community, they themselves institute a form of causality: they must form a community, because they now share an experience. Their contingent experience is thus retroactively converted into the shared essence of (a) being together.

This conversion cannot help but to seem ridiculous to the reader, even tragic through the very manner in which the close community of friends comes into being. We have no idea why they are together; they do not know each other but act as if they wanted to be together, as five and not as six. They act as if they are one, although they most certainly are not and they realize it doesn't make sense; they only act as if they share an essence with each other, but no one apparently knows what to call this essence. Kafka not only nuances the difference between the inside and outside of a community, he ironizes the way a community shuts itself off in general. If a contingent shared experience can just as easily form the basis of (a) communality, what then does it mean for people to share an "essence" with each other?

Must we conclude, then, with Kafka but also with Borges, that everything is contingent and relative? By no means. There are always communities to which some people belong and others do not. It is not that either there are substantial or strong communities or there are only unstructured meetings of individuals. It concerns rather the ways a community constitutes itself and on which basis. In Kafka's and Borges' short stories it becomes clear that the erection of a barrier, however contingent or capricious, always has a violent underside if one regards such a border as absolute and appropriates it as the sole authentic border. In such cases, the border or the limit becomes a dividing line between those who share the communal essence and those who do not. The limit is not only used to keep people out or refuse entry but also to align the members of the community to one another along an immanent axis.

When we reflect upon the caring organization, as this article pretends to do, we think it is important to take our time to understand how we understand an organization in the line between mere individuals and a strong community: is an organization a community, is it a fluid entity (Bauman, 2000), is it a fragmented gathering of people, etc. (Ignaas Devisch, 2013; Ignaas Devisch \& Francine, 2010; M. Heidegger, 1999; J.-L. Nancy, 2008, 2010; Rajchman, 1995; Ten Bos, 2005; Verhaeghe, 2014)?

\section{COMMUNITY}

Someone who profoundly thought about the importance of community in our contemporary world is French philosopher Jean-Luc Nancy. Community, he keeps on repeating, is one of the major problems of our era. Why indeed do we have to think community today, also during a conference on organization and care? The most obvious answer Nancy would give to the question is undoubtedly: because community is a problem today which also affects every kind of formal organization (J. L. Nancy, 1991, 1992a, 1999a, 2003).

It sounds rather banal to say we have to deal with something because it is a problem, but the question if of course why today community is a problem or at least a question and why we cannot but deal with it. (J. L. Nancy, 1991). There were times where it was selfevident who belonged to the community and who didn't, you were simply born in it. You were inside or outside of the house. Community then could not be a problem because the question of what it means to be in common did not even arise (I. Devisch, 2010). Whether these periods were better, simpler or more rosecolored is yet another but a very necessary question to all kinds or romantic nostalgia about a golden past; the 
fact is that community has not always been under discussion. In some periods, community was simply there, as the foundation and final cause of existence and the being of community was a sufficient reason for living together in a community (J. L. Nancy, 1992a).

Obviously today, this is not the case and one does not have to consult philosophical or ethical literature to see that community is indeed a problem, or at least is being conceived as problematic, and it is thus imperative to look for an answer to the problems that present themselves in thinking through our times (Macintyre, 1981). Since having clear insight into a problem is just as important as finding an answer, the question is: which problems are we dealing with in the context of community? The most basic and tautological answer is: the problem that we no longer know what we are talking about when we speak about community.

Here, too, the triviality of this answer speaks volumes but again, this is to Nancy a crucial insight in nowadays' society: the fact that we no longer know whether and how we can still speak about community, this is the fundamental challenge of community today. The most foundational evidence of a community - who belongs to it and why - is at loose ends and this is at least a challenge, not only to philosophy but to society as a whole (J.-L. Nancy \& Richardson, 2000). If every barrier of a community is contingent - think about Borges: if every classification fails - then the fundamental question raises how to organize society, since we cannot simply pretend that we are one world community and then presuppose all of our problems to be solved.

As far as Nancy concerns, we need new words and concepts to think our being together today, because the words by which we thought about community community is all about sharing the same essence: a color, a race, a nature, a nationality or a culture - is being eroded by the way society has evolved (Collective, 1991). A variety of cultural, political and social developments have led to the disappearance of traditional social bonds. A quick recounting of these developments would include the economic reduction of the importance of the old nation states through the increasing significance of transnational and global economic and cultural organization, rapid urbanization, greater complexity in terms of social and institutional structures and the progressive disintegration of ancient social connections and traditions. These have all contributed to the appearance of new insecurities and an increasing precariousness of our situation, both at the individual level and in the field of the social. Such insecurities have troubling effects not only on a number of social and political structures but also on our personal identities. Consequently, one of the most important uncertainties of today's society is that the traditional social bonds have dissolved and that we are confronted with the most basic questions. This is if course a golden age for philosophers who are most often fond of fundamental questions. So is Nancy. One of his major books on community is called Being singular plural (J.-L. Nancy \& Richardson, 2000). He argues that there is no singularity which is not plural and, the other way round, that there is no plurality which is not singular. To translate this into layman's terms: to be always implies to be more than one.

To Nancy, the 'more than one' is crucial: being never means being-alone but always being-with (J.-L. Nancy, 2008). Although this idea seems the most banal one-liner since decades, it is crucial in many discussions on identity and community. It implies that every enclosure of a community will always also be disclosed or disturbed from outside because the criteria used to enclose it are contingent. There will always be a sixth.

Nancy states that such insufficiency constitutes in principle every community. This must be regarded as fundamental, he concludes. The disclosure of a community is not derived from an originary or still-tobe-constituted completeness nor from a lack that the community is designed to sublate (J. L. Nancy, 1999a). Rather, such incompleteness is something constitutive because we are, be it as an individual person or as a collective identity, always exposed to others. For Nancy, the incompleteness is never located in some sort of quest for a closed totality. Insufficiency never stands for a lack, but for something that fundamentally cannot be perfected or finished and therefore is constitutive for every community. In short, closure goes hand in hand with disclosure and this challenges profoundly our thinking of the identity of for instance organizations. In Kafka's words: there is always a sixth. These dynamics will also have their influence within a rather formal gathering of people as organizations are: no matter how much rules and procedures we will develop, there will always be a sixth, within or outside the organization. We will come back to this.

Next to the incompleteness, a second characteristic Nancy puts forward is what he calls the singular character of identities (J.-L. Nancy \& Richardson, 2000). Singularity is not an easy concept. It refers to 
something that is rather ungraspable and unique, something hasty or fluid. These are, of course, no characteristics that will lead us towards a substance or essence of an organization. It rather appears to be the other way round: the lack of any essence seems to be the only essence of singularity (J. L. Nancy, 1992b).

Singularity represents the idea of a temporal identity, a non-substantial given changing all the time while existence goes on. In yet another text of Nancy, The Experience of Freedom, we find an interesting passage that might help us to answer this question: "For us, existence is above all what is singular. It happens singularly and only singularly. As for the existence, its own existence is above all singular, which means that its existence is not precisely its 'own' and that its 'existing' happens an indefinite number of times 'in' it's very individuality (which is for its part a singularity). Singularity is what distinguishes the existent from the subject, for the subject is essentially what appropriates itself, according to its own proximity and law. Yet the advent of a subjectivity is itself a singularity" (J. L. Nancy, 1993, pp. 190-191n192).

To accentuate the non-essential and temporary character of our identity as an individual or as part of a collective, not only Nancy but a lot of contemporary continental thinkers have used the notion of singularity. Many of them are or have been looking for a suitable concept to think identity in a non-substantial or nonessential way. Giorgio Agamben, Jacques Derrida, and Gilles Deleuze, to mention just a few names, have tried to make progress in thinking our identity in this way (Agamben, 1990; Bertland, 2011; Derrida, 1988, 1997a; Ignaas Devisch, 2012; Esposito, 2009; May, 1997; Patton, 1996). Most of them have an almost inborn fear from the political, philosophical, and social claim that identity can be seen as something that one owns. This does not only hold for an individual essence but also, and perhaps more urgently, for essences that believed to be shared collectively. Twentieth century politics have shown all too clear where the claim on closed substantial identities might lead to. Therefore, all of the thinkers named (and others), want to undo the possibility of this claim by thinking identity or existence in another way, in order to prevent us from totalitarian thinking (Traverso, 2001). This is also why we started this paper with the two stories: they question the idea of a closed identity.

While many thinkers put forward a strong individual identity against the risk of totalitarian collectivities, Nancy's specific touch in this debate is the explicit relation he establishes between singularity and plurality. He argues that there is no singularity which is not plural and, the other way round, that there is no plurality which is not singular: being is always beingwith, singular is always singular plural, being one is always being more than one. The singularity is a plurality, with and between other singularities (which are, by the same token, also pluralities). Nancy speaks of the 'singular plural in such a way as to make clear that singularity is inextricably bound up with plurality. Singularity is being-with-many (J.-L. Nancy, 2008; J.-L. Nancy \& Richardson, 2000).

To singularize oneself means to be exposed to others and to differ from others. The relation between singularities is their incommensurability. They can never be reduced to one another, but their mutual differences never boil down to substantial characteristics which can lead towards the closure of a collective of similar singularities. We are different from one another, but not out of a substance or archetype. Characteristics like ethnicity or culture are contingent, in a way that they are not the exclusive and substantial key terms to include or exclude a person to a certain community or organization. Admittedly, there are Germans and others who are not, there are laborers and others who are not, or there are Muslims and others who are not, but here Nancy crucially points out these people do not differ in a substantial way from the others since there is no infinite and everlasting native essence called 'German', 'laborer', or 'Muslim'. Because of their singularisation, identities differ from themselves and can no longer be thought of as a substance to which one, depending on whether one shares the putative essence of the collective identity, belongs or not. Identities, be it collectives or individuals, are contingent in a way that they change with every singularization. Each time again, they are recomposed, rebuild, and modified. Not that they are just like anything or anyone else. They are a 'self' but this self is only in its respective singular moments each time again different from the other moments (J.-L. Nancy \& Rand, 2008).

Kafka's story in which the five conceived themselves as one and the sixth represented their 'more than one' reveals the starting point Nancy stands upon in his writings on community and singularity and the way he develops a new thought on individual or collective identity. Identity, he claims, is no vast and steady entity, grounding itself. Neither is a collective, thought out in terms of a substantial criterion that allegedly marks the frontier between inner and outer. 
Both the individual and the collective exist in their respective singularization. They change all the time and so do their characteristics.

Thinking this change is as such not innovative - of course, we change all the time - but it gets radicalized in Nancy's thought. Nancy does not start with the essence of an identity which then is subject to some changes. It is just the other way round: identity is nothing but the gathering of singular differences, the infra-individual differences that make someone always plurally, locally and momentarily different.

Existence is without essence and that is what Nancy's singularity is all about. If we all are singular and thus plural, we neither do have an essence nor are we substantial individuals: "At this exact point, then, one becomes most aware of the essence of singularity: it is not individuality; it is, each time, the punctuality of a 'with' that establishes a certain origin of meaning and connects it to an infinity of other possible origins. Therefore, it is, at one and the same time, infra/intraindividual and transindividual, and always the two together. The individual is an intersection of singularities, the discrete exposition of their simultaneity, an exposition that is both discrete and transitory" (J.-L. Nancy \& Richardson, 2000, p. 85).

Consequently, we do not differ just from others but we also differ continuously from ourselves. With a friend we behave differently than with family. In different contexts we can also behave differently toward the same person. People never meet person $Y$ as such, but always person $Y$ with specific infraindividual qualities or characteristics. This is why people are not to be distinguished from each other on the basis of whether or not they share a common denominator. There are no archetypal points of comparison or one or another essence against which each character trait can be measured. The smile of an African girl does not typify the girl on the basis of some substantial characteristics of either being black or African. The smile typifies the girl at that moment, at that fleeting moment at which she laughs. Each new situation brings another smile (or tear) and thus another origin or singular moment (J.-L. Nancy \& Rand, 2008).

\section{WHAT ABOUT AN ORGANIZATION?}

What can this possibly mean for an organization? An organization, as is often pretended in commercials or baselines, would have a kind of fixed identity, a set of essential characteristics that we might refer to as the organization culture, and so on. And also people are appealed to work at company $\mathrm{X}$ or $\mathrm{Y}$ because this company is this or that. In this perspective, an organization is understood as a 'whole' where workers substantially identify themselves with, with mission statements, the specific company cultures, or whatever. To be part of the whole would imply to identify you with it, to embody it and to become as one with the organization. Individual and collective are thus pinned down to a substantial criterion, an essence, a strong and steady 'self'.

When identity is understood as a permanent given or essence then every characteristic referring to something else, something from outside, is then identified as a threat, as a sort of virus contaminating the pure identity of the organizations identity or image (Boyd, 2000). For an organization then, the individual subject is a strange entity it has to 'adapt' in order to make it functional for the organization. As an individual, you will become one of them if you start working there; we all know that sort of expensive slogans.

To refer again to Kafka: in this story, the company then represents the five friends and we are the sixth but contrary to Kafka's story, 5+ 1= 5 here; we may enter into the house as long we reduce ourselves to a part of the whole.

Thinking an organization from the perspective of singularity means that we no longer think in terms of an unchangeable essence (Ten Bos, 2005). Nancy's notion of the singular goes the other way round: organizations are able to function because they differ from themselves and change all the time. The revolutionary about that is of course not the idea that we change all the time; in particular in business we always demand for changes. This is not Nancy's point, nor is he dreaming of a postmodern ontological conundrum that renders everything the same, that makes every truth merely relative and that leads us to believe that the world is too complex to be known.

Of greater innovative relevance is the idea that not only with every new employee, an organization's identity has changed, but also that the singular identity of all employees is changing all the time. The organization is but its components with their singular traits at that very moment and these traits produce a singularized and thus necessarily temporary collective.

This seems superficial but it implies a lot. As long as we start from identity as a substantial given, an 
unfruitful opposition is at work: the collective, the organization, is seen as the enemy of the subject and vice versa. From this perspective, individuals should adapt to enter the identity and if not, they remain an intruder, an outsider or if we would moralize them, they become stubborn employees who refuse to adapt their behavior to the company.

Nancy's notion of singularity on the contrary, does not start from an opposition of two identities but from identities differing from themselves because they are understood as singular, changing entities and precisely their singular characteristics at that very moment will potentially modify the whole as such (Pryor, 2004). Consequently, an organization has all reasons to face the question of singularity. For instance a typical argument from a loyal worker who is asked to move to another working place is: 'I like it here, I don't want to move'. This answer is in a sense very substantial: the employee supposes that working culture, work floor organization, and so on will stay the same during his or her whole career and that is why s/he does not want to leave. But those are conditions s/he can of course never be sure of.

The singularized answer would be more something like that: I like it 'here and now'. Because so many aspects and evolutions can impact on the job, it can be completely changed within even the shortest of periods. Organizations are not always places of stability. The reasons the employee offers when he refuses to go may not be available after change has set in: a new boss, a new colleague, other tasks to be carried out, a new owner of the organization, anything can happen. Within every change in conditions, we can potentially speak of a new constellation or singularization of the relation between the organization and the employee. The classic relation between them, often premised on concepts such as job security or lifelong loyalty, does no longer exist. Neither can we still speak of a relation between the whole and its parts, between the collective and its individual members. What makes of an organization each time again a singularized entity? It are the temporary and unique constellations, based on the way employees behave, the policy of the organization, the traffic, the mood of the people at that very moment, the outside temperature, the loss of Manchester United the evening before in the Champions League, the whatever and many other aspects.

Traditionally, an organization tries to suppress all these temporary influences of their employees and of the environment or society in general. An organization does not want the employee to malfunction because of the loss of Manchester United. It wants him or her to do the job, quite irrespective of whatever emotional state the employee is in. And the more structured and planned the acts of the employees are (do this, then this, ...), the less singularity can play its role. As such this is a pity because one can also, besides the evident counterarguments, reveal many opportunities here where an organization could function better if it would be interested in singularity. It is in this prospect that we want to tackle the importance of care in an organization.

\section{TAKING CARE}

What we are suggesting here is not some sort of a critique of business ethics or of caring organizations, but rather as an attempt to open up a space of thinking before it gets closed by some ethical image we all have to expose because it is fashionable to call yourself a caring organization. Taking care of people is the core business of a caring organization and this has to be more than window dressing.

Ethics has to do with right procedures but is so much more. To give a very extreme example: we don't think that taking care of a warm cell and fancy clothes in Guantanamo after you were waterboarding a prisoner, is an ethical practice; foreclosing Guantanamo, that would be a truly ethical act. As such, the use of the word 'ethics' is no guarantee for an ethical practice.

Our distrust with the widespread use of ethics was and is based upon the speed by which the word all of a sudden had become fashionable. When and because words become well-known, no one still questions their meaning for the simple reason that because they are well known; it would be embarrassing not to know its meaning. So instead of asking what the word means, one decides to pretend as if one knows what it means by saying, 'ethics?', of course we agree.

Consequently, in dealing with ethical topics we have to be aware of that. As philosophers as Martin Heidegger and Jacques Derrida have demonstrated, the way we question something always already determines our answer to the problem (Derrida, 1997b; Martin Heidegger \& Macquarrie, 1962). If we ask ourselves, how can we develop procedures to take care of people, we presuppose that taking care can be settled with right procedures. This is a matter of 
distrusting yourself at the very moment you think you're doing the right thing.

If we distrust ourselves in the context of a caring organization, the toughest question is to ask ourselves: does care only start at the very moment we are posing this question, or are we already put into a caring relationship towards the world and the others before we start to develop procedures, formats and baselines do deal with it? Is a caring organization something we can organize or does the care include a responsibility which precedes our initiative to care? We think this would be Nancy's question. Let us return a final time to his writings to unravel this.

In The Experience of Freedom, Nancy states that justice today can no longer be that of a right environment presupposing a given measure (J. L. Nancy, 1993). By this, he refers to the ontological order of an (ancient) world that gave a central function to the idea of a just measure. Unlike the antique or feudal order in which the structure of the world is given to man, a modern society starts from the idea that there is no presupposed order or measure in the world. With the withdrawal of God in the modern era as the founding principle of the universe, creation is thrown back increasingly on itself, Nancy writes in his essay 'Human excess' (J.-L. Nancy \& Richardson, 2000, pp. 177-183). Lacking any criterion or limit point, it becomes its own measure.

This is what we appreciate at most of modernity: as human beings, we can do what we want. We are who we want to be. And indeed, metaphysically speaking, never before our freedom was so radical. But as is often the case, there is also a reverse side of this freedom. If anyone but man is left to cope with our freedom, there is nothing to fall back upon. If we can do what we want, there is also no escape from it. Consequently, to do what one wants turns into 'we have to do what we want'. Once the Gods have flown away, we cannot escape from the fact that we are free and we are the only ones to take up the challenge.

This is why Nancy confronts us with a quite annoying question: If the just measure has collapsed, does it not mean that we are the only ones left to be responsible for the world? But how to understand our responsibility? If the world is measuring itself, if 'man' is the measure of all things, we acquire an immense responsibility for the whole of existence. In The Experience of Freedom, Nancy describes this 'total responsibility' and in 'Responding for existence' he calls it an archi-responsibility (J. L. Nancy, 1999b). By this, he understands the fact that our responsibility does not stem from a just measure or from a self that is responsible only for its own legal obligations. Archiresponsibility precedes all measures and laws. This does not imply that one always and for all time has to bear an unlimited responsibility, or that political or moral, juridical responsibility is not to be assessed in concrete situations. This assessment is also a responsibility but once the measure for it is no longer given in advance, all assessment of responsibility always and already starts from this archi-responsibility.

Archi-responsibility is a responsibility 'before' responsibility. It means that in Nancy's philosophy, responsibility is something that precedes our initiative to be responsible, it is not an option but something we are always thrown into. To be responsible, Nancy writes, is not to expel yourself from this condition (J. L. Nancy, 1999b). As Heidegger already stated, because we are thrown into the world, we have the possibility of regarding this 'thrownness' as our own and of deciding to take our existence in our own hands (Martin Heidegger \& Macquarrie, 1962). To Nancy, the fact that something in existence precedes our own initiative is crucial. It is only because man is understood as a free agency, we are able to take responsibility in the most literal sense of the word: the Latin words 'respondere' and 'res-pondeo' contain 'res' and 'sponsio'. 'Res' stands for thing, matter, while 'sponsio' means a religious or judicial engagement - think about the English word 'spouse' or the French 'épouse'. 'Respondere' or 'spondere' mean 'answer to' or 'promise in return'; to respond was also part of the Christian liturgy said or sung by the congregation in reply to the priest (J. L. Nancy, 2001).

To respond therefore means to encounter, to answer a promise, to get engaged in something coming from elsewhere; which implies responsibility is always a matter of more than one individual enclosed upon itself (See also: Altman, 2007). To be responsible is to answer an engagement or an appeal, to be opened towards the outside, towards others and to take part of the world. Dictionaries mention that only from the second half of nineteenth century, responsibility involves obligations or duties as we understand them today. Earlier on, it was a word to express the capability of answering, to get engaged in a social relationship so to say (Brown, 1993). Therefore, Nancy writes, in the original sense, to be responsible is to be engaged towards others. 


\section{CONCLUSION}

What kind of conclusions can we deduce from Nancy's work? Of course, it is always hard to make the transition from a practical balancing of how to organize things with this kind of fundamental, ontological thought. To understand what Nancy is up to, it is crucial to go back to the basic questions: how do we think about identity, about an organisation and how do we understand care? It is obvious that Nancy tries to tell us something at this very fundamental level.

First of all, Nancy can make us aware that being responsible or taking care is not only something you can manage. In the context of the caring organization, it implies a lot. Taking care is not only a problem of daily management but also of thinking about how we understand human identity, how we conceive an organization as a collective identity, et cetera. Often, we start from very substantial ideas in this context: an organization stands for $\mathrm{X}$, a person stands for $\mathrm{Y}$ and the main problem of management is how can we make them work together, be it in a context of care or not. One can with concepts such as singularity think of a job or an organization in far less substantial ways. Every one of us has periods in his life where he is creative and happy or when is in an emotional crises or suffers from a complete burn-out. When people have to do the same job during their whole life in the same way, one loses at lot. With some flexibility and the suitable incentives, one can stimulate employees in creative periods to fulfill other tasks, to work at other places in the factory, or to allow for the possibility to have people formulate novel ideas concerning the organization of their factory. In busy periods for employees (e.g. the nursing of little children at home), one can foresee the time and the place to step back for a period, be it part time, be it with let them fulfilling other tasks, and so forth. There are endless possibilities here. During certain periods, an organization needs more creativity, working hours or new ideas than during other periods of relative stability. Why not try to match these periods with the impulses coming from people working for the organization?

Maybe singularity can play a certain role in processes of organizational change and resist the idea that it should be suppressed at all cost in organizational settings. Why should not an employee or a manager learn to think in terms of jobs they can do rather than in terms of jobs they have to do? The more working places are organized in a bureaucratic and 'neurotic' way, the less they give singularity the space to develop the opportunities it can offer.
Of course singularity is not a magic formula that will somehow reorganize our whole society. Far from that. If it has a function to fulfill, that is to say, if we can allow it to happen - and this is what is at stake in Nancy's writing - it seems to play a rather 'modest' role. You cannot change an organization by the whim of a manager or the smile of a girl. But singularity does happen, also in organizations, and it has perhaps some potentiality to bring in new and creative ideas on law, work, labor, culture, and so on. To allow it to happen rather than merely resisting it requires a rethinking of many of our frameworks that determine our views on work and organizations in general: the part-whole thinking or the substantial views on identities of subjects in general, and the emphasis on strong organizational cultures are only a few of them. A lot of thinking awaits us here, be it with or without Nancy, Borges or Kafka.

Secondly, the matter of responsibility. For sure, it is necessary to manage care and the problems we are facing with. But it can also be very useful and even necessary to be aware of responsibility which does not start nor end with the right procedures we develop for this (See also: Decoste \& Boyd, 2009). Responsibility means more than that. If Nancy writes we must do justice to existence, by that he never means thé existence as such but always singular existences to which we do justice (or not). In being responsible, we are not talking to history but to peoplewho are not simply migrants, or workers, or whoever, but singular identities. Maybe our responsibility is also to be creative in thinking how to respond to the sixth person in Kafka's story. It is easy to exclude him and to say: sorry, the door is closed. In an organization, we never know what the next day will bring us: maybe we will need a sixth one. Although today he can be disturbing, tomorrow he may be very interesting.

\section{REFERENCES}

Agamben, G. (1990). La communauté qui vient. Paris: Seuil.

Altman, M. C. (2007). The Decomposition of the Corporate Body: What Kant Cannot Contribute to Business Ethics. Journal of Business Ethics, 74(3), 253-266. http://dx.doi.org/10.1007/s10551-006-9233-z

Anderson, B. (1999). Imagined communities. Reflections on the origin and spread of nationalism. London: Verso.

Anderson, N., \& Hughes Karen, D. (2010). The Business of Caring: Women's Self-Employment and the Marketization of Care. Gender, Work \&amp; Organization, 17(4), 381-405.

Bauman, Z. (2000). Liquid Modernity. Cambridge: Polity Press.

Bertland, A. (2011). The Limits of Workplace Community: Jean-Luc Nancy and the Possibility of Teambuilding. Journal of Business Ethics, 99(1), 1-8.

http://dx.doi.org/10.1007/s10551-011-1156-7 
Borges, J. L. (1984). The book of imaginary beings (N. T. d. Giovanni, Trans.). Harmondsworth: Penguin Classics.

Boyd, K. M. (2000). Disease, illness, sickness, health, healing and wholeness: exploring some elusive concepts. Med.Humanit., 26(1), 9-17.

http://dx.doi.org/10.1136/mh.26.1.9

Brown, L. (1993). The new shorter Oxford English dictionary. Oxford: Clarendon Press.

Campbell, K. (2011). Caring and daring entrepreneurship research. Entrepreneurship \&amp;\#x26; Regional Development, 23(12), 37-47. http://dx.doi.org/10.1080/08985626.2011.540407

Collective, M. T. (1991). Community at loose ends. Minneapolis Oxford: University Of Minnesota Press.

Decoste, J., \& Boyd, D. (2009). An "Ideal" Home for Care: Nel Noddings, Thomas Hill Green, and an Ontological Support for a Phenomenology of Care. Interchange (Toronto. 1984), 40(3), 309-334.

http://dx.doi.org/10.1007/s10780-009-9094-3

Derrida, J. (1988). The politics of friendship. The journal of philosophy, 85(1), 632-644.

Derrida, J. (1997a). Dissemination. London: Athlone Press.

Derrida, J. (1997b). Of grammatology. Baltimore: John Hopkins University Press.

Devisch, I. (2010). The disclosure of a metaphysical horizon, or how to escape dialectics. South African Journal of Philosophy, 29(1), 17-27.

http://dx.doi.org/10.4314/sajpem.v29i1.54451

Devisch, I. (2012). Jean-Luc Nancy and the question of community. London: Continuum - Bloomsbury.

Devisch, I. (2013). HOW (NOT) TO PROPERLY ABANDON THE IMPROPER? Angelaki-Journal of the Theoretical Humanities, 18(3), 69-81. http://dx.doi.org/10.1080/0969725X.2013.834665

Devisch, I., \& Francine, W. (2010). Meeting a patient as a singular event. A philosophical reflection. Aporia, 2(1), 19-24.

Esposito, R. (2009). Community and nihilism. Cosmos and history, 5(1), 24-36.

Forte, A. (2004). Business Ethics: A Study of the Moral Reasoning of Selected Business Managers and the Influence of Organizational Ethical Climate. Journal of Business Ethics, 51(2), 167-173. http://dx.doi.org/10.1023/B:BUSI.0000033610.35181.ef

French, W., \& Weis, A. (2000). An Ethics of Care or an Ethics of Justice. Journal of Business Ethics, 27(1-2), 125-136. http://dx.doi.org/10.1023/A:1006466520477

Heidegger, M. (1999). Identität und Differenz. Stuttgart: Neske. Elfte Auflage.

Heidegger, M., \& Macquarrie, J. (1962). Being and time / Martin Heidegger; transl. by John Macquarrie e.a: Harper and Row.

Kafka, F. (1983). The complete stories. New York: Schocken Books.
Lopez, J. (2003). Society and its metaphors. Language, social theory and social structure. New York: Continuum.

Macintyre, A. (1981). After virtue. A study in moral theory. London: Duckworth.

May, T. (1997). Reconsidering difference. Nancy, Derrida, Levinas, and Deleuze. University Park, Pennsylvania: The Pennsylvania State University Press.

Nancy, J.-L. (2008). The being-with of being-there. Continental Philosophy Review, 41(1), 1-15. http://dx.doi.org/10.1007/s11007-007-9071-4

Nancy, J.-L. (2010). Identité. Fragments, franchises. Paris: Galilée.

Nancy, J.-L., \& Rand, R. (2008). Corpus: Fordham University Press.

Nancy, J.-L., \& Richardson, R. (2000). Being singular plural / Nancy, Jean-Luc ; transl. by Robert D. Richardson e.a: Stanford university press.

Nancy, J. L. (1991). The inoperative community. Minneapolis: University of Minnesota Press.

Nancy, J. L. (1992a). La comparution/ The compearence from the existence of "communism" to the community of "existence". Political theory, 20(3), 371-398. http://dx.doi.org/10.1177/0090591792020003001

Nancy, J. L. (1992b). Un sujet? Homme et sujet (pp. 47-114). Paris: L'Harmattan.

Nancy, J. L. (1993). The experience of freedom. Trans. Bridget McDonald with a forword by Peter Fenves. Stanford: Stanford University Press.

Nancy, J. L. (1999a). The question of community. The practical philosophy of Jean-Luc Nancy. Studies in practical philosophy.A journal of ethical and political philosophy, 1(1).

Nancy, J. L. (1999b). Responding for existence. Studies in practical philosophy, 1(1), 1-11. http://dx.doi.org/10.5840/studpracphil1999112

Nancy, J. L. (2001). La pensée dérobée. Paris: Galilée.

Nancy, J. L. (2003). The confronted community. Postcolonial Studies, 6(1), 23-36 http://dx.doi.org/10.1080/13688790308110

Patton, P. (1996). Deleuze. A critical reader: Basil Blackwell.

Pryor, B. S. (2004). Law in abandon: jean-luc nancy and the critical study of law. Law and Critique, 15(3), 259-285. http://dx.doi.org/10.1007/s10978-004-5444-6

Rajchman, J. (1995). The identity in question. New York \& London: Routledge.

Ten Bos, R. (2005). Giorgio Agamben and the community without identity. In C. Jones \& M. R. (Eds.), Contemporary organization theory. Oxford: Blackwell. http://dx.doi.org/10.1111/j.1467-954x.2005.00538.x

Traverso, E. (2001). Le totalitarisme. Le XXième siècle en débat. Paris: Seuil.

Verhaeghe, P. (2014). What about Me?: the struggle for identity in a market-based society. Brunswick: Scribe.

(C) 2015 Ignaas Devisch; Licensee Lifescience Global.

This is an open access article licensed under the terms of the Creative Commons Attribution Non-Commercial License (http://creativecommons.org/licenses/by-nc/3.0/) which permits unrestricted, non-commercial use, distribution and reproduction in any medium, provided the work is properly cited. 